\title{
PENALTIES REGIMES TO COUNTER CORPORATE AND FINANCIAL WRONGDOING IN AUSTRALIA - VIEWS OF GOVERNANCE PROFESSIONALS *
}

\author{
George Gilligan, Andrew Godwin, Jasper Hedges and lan Ramsay**
}

\begin{abstract}
The issues of corporate misconduct, its effects and how regulators and other law enforcement actors respond to such behaviour are increasingly contentious in Australia and overseas. In the wake of a succession of scandals in recent years in Australia's financial sector there has been much debate about whether the penalties regimes available to the Australian Securities and Investments Commission (ASIC) are adequate and whether they are being implemented effectively. This paper discusses these issues drawing upon the results of an online survey of members of Governance Institute of Australia (GIA) conducted in mid-2016 by researchers at the University of Melbourne. The survey responses, $(n=365)$, provide interesting insights into how penalties regimes to counter corporate misconduct are perceived by governance professionals.
\end{abstract}

Keywords: $\quad$ Corporate misconduct, enforcement, governance, penalties

* Funding for this research was provided by the Centre for International Finance and Regulation (Grant T021) and the University of Melbourne.

** George Gilligan is a Senior Research Fellow, Andrew Godwin is an Associate Professor, Jasper Hedges is a Research Fellow and lan Ramsay is the Harold Ford Professor of Commercial Law and Director of the Centre for Corporate Law and Securities Regulation, Melbourne Law School, the University of Melbourne. The authors acknowledge the statistical support provided by Malcolm Anderson.

Corresponding author: Ian Ramsay, Melbourne Law School, the University of Melbourne, 185 Pelham Street, Carlton, Victoria, 3053, Australia, email: i.ramsay@unimelb.edu.au

George Gilligan, Melbourne Law School, the University of Melbourne, 185 Pelham Street, Carlton, Victoria, 3053, Australia

Andrew Godwin, Melbourne Law School, the University of Melbourne, 185 Pelham Street, Carlton, Victoria, 3053, Australia

Jasper Hedges, Melbourne Law School, the University of Melbourne, 185 Pelham Street, Carlton, Victoria, 3053, Australia 


\title{
Part I Introduction
}

Current penalties generally provide no disincentive from continuing to break the law, in fact they are generally seen as an incentive. The benefits of breaking the law far outweigh the penalties, on the few occasions they are enforced.

\begin{abstract}
$* * *$
The fines and penalties are totally inadequate in the area of "white collar crimes", specifically within the corporate world. The penalties and fines should match and be equivalent to those issued under the normal judiciary for crimes which are pursued under common law.

$* * *$

Although there is a range of penalties, they are rarely imposed at the maximum and for the signalling impact they need to be significantly larger and more direct.

$* * *$

Penalties are too low and need to hurt the company and directors so they do not even think about trying to get around the law.
\end{abstract}

The above quotes are a small snapshot of some of the comments by participants in an anonymous online survey of Australian governance professionals, (discussed in Part II and below), which sought their views as to the adequacy and effectiveness of penalties regimes to counter corporate and financial wrongdoing in Australia. The sample quotes above attest to widespread disquiet in recent years about the capacity of contemporary penalties regimes in Australia to counter corporate wrongdoing. For example, in an address at the National Press Club in Canberra on 3 December 2014, Chair of the Australian Securities and Investments Commission (ASIC), Mr Greg Medcraft stressed that penalties regimes available to ASIC are insufficient:

Breaking the law in the financial sector seems to be a trade-off between fear and greed. So, Australia needs penalties that amplify the fear and suppress the greed. Australia needs penalties that will scare the pants off people. ${ }^{1}$

A number of government and other public inquiries have been sympathetic to the challenges faced by ASIC and the perceived adequacy of ASIC's penalties regimes. They have emphasised the linkages between ASIC's available powers and penalties and its capability to meet its regulatory objectives. For example, in its Final Report the Financial System Inquiry (FSI), chaired by Mr David Murray AM, recommended that ASIC be strengthened: '...including better funding, enhanced regulatory tools...stronger licensing powers to address misconduct, and substantially higher criminal and civil penalties'. ${ }^{2}$ In July 2015, ${ }^{3}$ then Assistant Treasurer Josh Frydenberg commissioned a capability review of ASIC, which reported to Treasury in December 2015. The capability review's final report was released on 20 April 2016 and it made 34 recommendations including improvements to ASIC's regulatory toolkit

\footnotetext{
${ }^{1}$ Medcraft G, 'ASIC explained: Who is the corporate watchdog, what does it do and why should Australians care?' (Speech delivered at the National Press Club of Australia, Canberra, 3 December 2014), p.7, http://asic.gov.au/about-asic/media-centre/speeches/asic-explained-who-is-the-corporate-watchdog-whatdoes-it-do-and-why-should-australians-care (accessed 8 February 2017).

${ }^{2}$ Commonwealth of Australia, Financial System Inquiry Final Report (Canberra, 2014) p.236, http://fsi.gov.au/files/2014/12/FSI_Final_Report_Consolidated20141210.pdf

${ }^{3}$ Australian Government, The Treasury, Capability Review of the Australian Securities and Investments Commission, 2015, http://www.treasury.gov.au/ConsultationsandReviews/Reviews/2015/ASIC
} 
(recommendations 27 and 28). ${ }^{4}$ The Australian Government had already committed to a '...review of ASIC's enforcement regime, including penalties and the financial services licensing breach notification framework, in 2017...' which was its response to recommendation 29 of the FSI. ${ }^{5}$ Prime Minister Turnbull himself has been critical of prevailing professional standards within Australia's major banks and the Australian financial sector more generally, questioning whether incentives, including penalties regimes, were stimulating sufficiently good behaviour by financial professionals. ${ }^{6}$

Prime Minister Turnbull's criticisms reflect a familiar litany of financial scandals in Australia characterised by poor, indeed sometimes deceptive and illegal behaviour by financial professionals seemingly unfazed by the deterrent capacities of existing penalties regimes. The roll call of infamy includes many well-known names. For example, in 2004 major Australian bank NAB announced that it had suffered losses of $\$ 360$ million due to unauthorised foreign currency trading by four of its employees who concealed the losses. ${ }^{7}$ Trio Capital Group was placed into external administration by its directors in December 2009. It was later revealed that Trio's approval of fraudulent transactions and signing of fake documents had contributed significantly to more than six thousand investors, mostly Australian superannuants losing more than $\$ 176,000,000 .{ }^{8}$ Australia's largest bank the Commonwealth Bank of Australia (CBA) has been embroiled in several scandals in recent years, including the illegal behaviour of some employees in a CBA subsidiary Commonwealth Financial Planning Limited (CFPL). A damning Senate Inquiry report in June 2014 revealed systematic misconduct affecting substantial numbers of clients and up to $\$ 300$ million in client money, including forging client signatures, creating unauthorised investment accounts and overcharging fees; the Inquiry Chair described past practices at CFPL as 'appalling', and the conduct of a number of CFPL advisers as: '...unethical, dishonest, well below professional standards and a grievous breach of their duties. $^{\prime 9}$ These scandals and many others in recent years such as the Great Southern and Timbercorp agribusiness managed investment scheme collapses, ${ }^{10}$ which resulted in hundreds of millions of dollars in losses to Australian retail investors, raise questions about the ability of Australian regulatory infrastructures, including their penalties regimes, to ensure that the Australian financial sector sufficiently protects investors from dishonest and unscrupulous financial professionals.

\footnotetext{
${ }^{4}$ Australian Government, The Treasury, Fit For The Future: A Capability Review of the Australian Securities and Investments Commission, A Report to Government, April 2016, p.131, http://www.treasury.gov.au/PublicationsAndMedia/Publications/2016/ASIC-capability-review

${ }^{5}$ Commonwealth of Australia, Improving Australia's Financial System, Government Response to the Financial System Inquiry, November 2015, p.24

http://www.treasury.gov.au/ /media/Treasury/Publications\%20and\%20Media/Publications/2015/Governmen t\%20response\%20to\%20the\%20Financial\%20System\%20Inquiry/Downloads/PDF/Government_response_to_F SI_2015.ashx

${ }^{6}$ See for example: Crowe D and White A, 'Malcolm Turnbull lashes banks over treatment of customers', The Australian (Sydney), 6 April 2016, http://www.theaustralian.com.au/business/financial-services/malcolmturnbull-lashes-banks-over-treatment-of-customers-advice-scandals/newsstory/7ed29a09534ca42c7d3cf0a9495c74c7.

${ }^{7}$ Dellaportas, S, Cooper, B.J. and Braica, P. (2007), Leadership, culture and employee deceit: the case of the National Australia Bank, Corporate governance: an international review, vol. 15, no. 6, pp. 1442-1452.

${ }^{8}$ Australian Government, The Treasury, Review of the Trio Capital fraud and assessment of the regulatory framework, April 2013, http://www.treasury.gov.au/PublicationsAndMedia/Publications/2013/Trio-Capitalfraud-review

${ }^{9}$ Senate Economics References Committee, the performance of the Australian Securities and Investments Commission, Media Release, 26 June 2014, p.1,

http://www.aph.gov.au/Parliamentary_Business/Committees/Senate/Economics/ASIC/Media_Releases

${ }^{10}$ Commonwealth of Australia, Senate Economics References Committee, Agribusiness managed investment schemes, Bitter harvest, (Canberra, March 2016, http://www.aph.gov.au/Parliamentary_Business/Committees/Senate/Economics/MIS/Report
} 
The Senate is still concerned about the adequacy and effectiveness of Australia's penalties regimes to deter and prevent corporate misconduct and white collar crime, and not just in the financial sector. On 25 November 2015, the Senate referred an inquiry into penalties for corporate and financial misconduct or white-collar crime to the Senate Economics References Committee for inquiry and report by 27 July 2016. The focus of this inquiry is on the inconsistencies and inadequacies of current criminal, civil and administrative penalties, with particular reference to, among other things, evidentiary standards, the use and duration of custodial sentences and the use and duration of banning orders. At the dissolution of the Senate and the House of Representatives on 9 May 2016 for a general election on 2 July 2016, the parliamentary committees of the $44^{\text {th }}$ Parliament ceased to exist. Therefore inquiries that were not completed lapsed. However subsequent to that general election, on 13 September 2016, the Senate agreed that this inquiry be re-adopted in the 45th Parliament and the committee reported on 23 March $2017 .{ }^{11}$

This important inquiry reflects ongoing deep parliamentary and community concern not only that financial scandals and other forms of corporate misconduct have been so pernicious and common in Australia, but also that existing penalties regimes to counter such behaviour have not been successful. However, if penalties regimes are to be successful, one must consider not only their reach and process, but also their strategic underpinnings. In Australia, as in most societies, the most commonly acknowledged rationales for punishment are: deterrence (including both general and specific deterrence); incapacitation; rehabilitation; restoration; and retribution. ${ }^{12}$ All of these rationales inform the enforcement strategy of ASIC by interacting with four key factors: (i) strategic significance (e.g. extent of the harm or loss); (ii) benefits of pursuing misconduct (e.g. costeffectiveness); (iii) features of the matter (e.g. available evidence); and (iv) non-investigative alternatives. ${ }^{13}$

ASIC has emphasised on many occasions that deterrence is its key punishment rationale and that its three core strategic outcomes are underpinned by deterrence goals: 'Effective regulation depends on achieving enforcement outcomes that act as a genuine deterrent to misconduct. The public expects ASIC to take strong action against corporate wrongdoers. Effective enforcement is therefore critical for us in pursuing our strategic priorities of promoting investor and financial consumer trust and confidence and ensuring fair and orderly markets. ${ }^{14}$ ASIC's emphasis on deterrence reflects international practice in both national and multi-lateral contexts. For example the UK's Financial Conduct Authority $(F C A)^{15}$ believes that successful enforcement of securities regulation is dependent on achieving credible deterrence and that is not possible without strong and effective penalties regimes. Similarly, the International Organization of Securities Commissions (IOSCO) argues that

\footnotetext{
${ }^{11}$ Commonwealth of Australia, Senate Economics References Committee, Inquiry into Criminal, Civil and Administrative Penalties for White Collar Crime, http://www.aph.gov.au/Parliamentary_Business/Committees/Senate/Economics/WhiteCollarCrime45th/Repo rt

${ }^{12}$ There is an extensive literature on the theory and practice of punishment. See for example: Ashworth A, Sentencing and Criminal Justice (Cambridge, Cambridge University Press, 1992); Beccaria C, On Crimes and Punishments (1963, (H. Paolucci, Trans), New York, NY: MacMillan, Original work published 1764); Garland D, Punishment and Modern Society, A Study in Social Theory (Oxford, Clarendon Press, 1991); and Lacey N, State Punishment (Abingdon, Routledge, 1988).

${ }^{13}$ Australian Securities and Investments Commission, ASIC's approach to enforcement, Information Sheet 151 (September 2013), http://asic.gov.au/about-asic/asic-investigations-and-enforcement/asic-s-approach-toenforcement

${ }^{14}$ Australian Securities and Investments Commission, Submission to Senate Economics References Committee, Inquiry into Criminal, Civil and Administrative Penalties for White Collar Crime, April 2016, 3-4, http://www.aph.gov.au/Parliamentary_Business/Committees/Senate/Economics/White_collar_crime/Submiss ions

${ }^{15}$ Financial Conduct Authority, Speech by McDermott T, Enforcement and Credible Deterrence in the FCA, 18 June 2013, http://www.fca.org.uk/your-fca/documents/enforcement-and-credible-deterrence-in-the-fca
} 
strong sanctions allied with certain and predictable consequences for misconduct are essential in order to achieve credible deterrence amongst offenders. ${ }^{16}$

The penalties debate is complex and at times can be confusing, with insufficient information available regarding the views on penalties of those who operate in the business community, especially those with gatekeeping responsibilities within organisations to prevent wrongdoing. In order to generate primary data in this area the project team partnered with Governance Institute of Australia (GIA). GIA is an independent professional association with more than 7,000 members which focuses on whole-of-organisation governance through its membership base of chartered secretaries, governance advisers and risk managers. GIA facilitates education and training, accreditation, provides knowledge resources and acts as an advocate for governance professionals in Australia. GIA has a strong commitment to research on governance issues, engaging with government on proposed legislative and regulatory reform and conducting research on issues relating to governance practices and trends. ${ }^{17} \mathrm{GIA}$ thus performs a crucial role in governance as an emerging field of study in Australia and its participation greatly enhanced the reach of the research study. In partnership with the authors GIA conducted an anonymous online survey to gather the views of governance professionals regarding the capacity of Australia's penalties regimes to counter corporate and financial wrongdoing. These findings are reported and analysed in Part II.

\section{Part II Project Survey of Governance Professionals}

\section{Survey Methodology}

The survey of GIA members was conducted using the online survey tool Survey Monkey from 21 April 2016 to 13 May 2016. The questions were devised in consultation with GIA's national policy committee and tested by a statistician during March and April 2016.

The survey was sent to the GIA online membership $(n=4,618)$, of whom 365 responded to the survey. The questions were mandatory but 19 of the respondents stopped answering questions partway through the survey, with 346 respondents completing every question. Many of the respondents provided written comments in addition to answering the multiple choice questions, with the number of comments in response to each question ranging from 45 to 92 .

The first day of the survey attracted 156 responses and a reminder email was sent on 5 May 2016 attracting a further 114 responses, while there were between 1 to 22 responses on the other days of the survey. The responses were anonymous and multiple responses from the same device were blocked so that respondents could not take the survey more than once. The data generated by the survey was analysed by running Ordinary Least Squares (OLS) regressions on the data using Statistical Package for the Social Sciences (SPSS). The findings are discussed below.

\section{Survey Findings}

Questions 1 - 10 sought respondents' views on specific issues relating to penalties regimes to counter corporate and financial wrongdoing. The responses to Q11 - which asked respondents if they had additional suggestions for how penalties for corporate and financial wrongdoing could be

\footnotetext{
${ }^{16}$ International Organisation of Securities Commissions (IOSCO), 'IOSCO Publishes Report on Credible Deterrence Approaches in Securities Market Regulation' (Media Release, IOSCO, June 2015), < https://www.iosco.org/news/pdf/IOSCONEWS383.pdf>

${ }^{17}$ See: Governance Institute of Australia, http://www.governanceinstitute.com.au/.
} 
improved, either in terms of the penalties themselves or how they are administered by ASIC and the courts - are explored below. The various tables displayed below which report the results of the total population sample to questions $1-10$ also provide a column showing the weighted average score. The weighted average score ranges from 1 to 5 and provides a gauge to the relative strength of the overall response by the total sample population. The weighted average is a sign of relative agreement, so the closer the score is to 1 then the greater the level of disagreement with the question posed and the closer to 5 the greater the level of agreement with the question.

As Table 1 shows the first question in the survey was relevant to the key issue of the credible deterrence capacity of available penalties regimes in Australia by asking respondents whether they believed the level of fines and other monetary penalties imposed by courts for corporate and financial wrongdoing were adequate.

Table 1. Adequacy of fines and other monetary penalties

Q.1 The level of fines and other monetary penalties imposed by courts for corporate and financial wrongdoing is adequate

\begin{tabular}{|l|l|l|l|l|l|l|l|}
\hline $\begin{array}{l}\text { Answer } \\
\text { Options }\end{array}$ & $\begin{array}{l}\text { Strongly } \\
\text { disagree }\end{array}$ & Disagree & No opinion & Agree & $\begin{array}{l}\text { Strongly } \\
\text { agree }\end{array}$ & $\begin{array}{l}\text { Weighted } \\
\text { Average }\end{array}$ & $\begin{array}{l}\text { Response } \\
\text { Count }\end{array}$ \\
\hline & $\begin{array}{l}87 \\
(23.84 \%)\end{array}$ & $\begin{array}{l}162 \\
(44.38 \%)\end{array}$ & $37(10.14 \%)$ & $\begin{array}{l}73 \\
(20 \%)\end{array}$ & $6(1.64 \%)$ & 2.31 & 365 \\
\hline
\end{tabular}

As indicated in Table 1, more than two thirds (68.2\%) disagreed or strongly disagreed, and less than a quarter $(21.6 \%)$ agreed or strongly agreed with this proposition. The weighted average of 2.31 (on a scale of 1-5), indicates significant dissatisfaction as a total population about the adequacy of fines and monetary penalties imposed by courts. This was shown in some of the additional comments provided by respondents, for example:

There is too much minimization being given by courts for 'monetary' crimes.

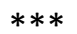

While the penalties such as disqualification of up to 5 years are adequate, the pecuniary penalties are very low especially since some of the culprits have got away with excessive remuneration and personal benefits.

Table 2. Adequacy of maximum monetary penalties for corporate and financial wrongdoing

Q.2 The $\$ 200,000$ maximum monetary penalty that courts can impose on an individual for a single contravention of a civil penalty provision of the Corporations Act 2001 (e.g. breach of directors' duties, failure to comply with financial services licensee requirements) is adequate

\begin{tabular}{|l|l|l|l|l|l|l|l|}
\hline $\begin{array}{l}\text { Answer } \\
\text { Options }\end{array}$ & $\begin{array}{l}\text { Strongly } \\
\text { disagree }\end{array}$ & Disagree & No opinion & Agree & $\begin{array}{l}\text { Strongly } \\
\text { agree }\end{array}$ & $\begin{array}{l}\text { Weighted } \\
\text { Average }\end{array}$ & $\begin{array}{l}\text { Response } \\
\text { Count }\end{array}$ \\
\hline & $\begin{array}{l}78 \\
(21.73 \%)\end{array}$ & $\begin{array}{l}164 \\
(45.68 \%)\end{array}$ & $22(6.13 \%)$ & $\begin{array}{l}88 \\
(24.51 \%)\end{array}$ & $7(1.95 \%)$ & 2.39 & 356 \\
\hline
\end{tabular}

Q2 continued the theme of probing about the capacity of penalties regimes to counter corporate and financial wrongdoing by asking respondents whether the $\$ 200,000$ maximum monetary penalty that courts can impose on an individual for a single contravention of a civil penalty provision of the Corporations Act 2001 (e.g. breach of directors' duties, failure to comply with financial services licensee requirements) is adequate. Table 2 above shows the overall results: more than two thirds $(67.41 \%)$ disagreed or strongly disagreed and just over a quarter (26.46\%) agreed or strongly agreed. 
The weighted average of 2.39 (on a scale of 1-5), indicates significant dissatisfaction as a total population about the $\$ 200,000$ available maximum penalty.

Q3 continued the theme of probing the capacity of penalties regimes to counter corporate and financial wrongdoing by asking respondents whether there should be no maximum limit on the monetary penalties that courts could impose and Table 3 below shows the overall results. There was a majority $(56.46 \%)$ that strongly agreed or agreed that there should be no maximum limit on the level of the monetary penalties that courts can impose for corporate and financial wrongdoing, but $39.32 \%$ strongly disagreed or disagreed with this proposition and this is reflected in the less pronounced weighted average of 3.26 in comparison to questions one and two.

Table 3. Maximum limits and monetary penalties for corporate and financial wrongdoing

\begin{tabular}{|c|c|c|c|c|c|c|c|}
\hline $\begin{array}{l}\text { Answer } \\
\text { Options }\end{array}$ & $\begin{array}{l}\text { Strongly } \\
\text { disagree }\end{array}$ & Disagree & No opinion & Agree & $\begin{array}{l}\text { Strongly } \\
\text { agree }\end{array}$ & $\begin{array}{l}\text { Weighted } \\
\text { Average }\end{array}$ & $\begin{array}{l}\text { Response } \\
\text { Count }\end{array}$ \\
\hline & $\begin{array}{l}37 \\
(10.39 \%)\end{array}$ & $\begin{array}{l}103 \\
\text { (28.93\%) }\end{array}$ & 15 (4.21\%) & $\begin{array}{l}131 \\
(36.80 \%)\end{array}$ & 70 (19.66\%) & 3.26 & 356 \\
\hline
\end{tabular}

Q4 was similar to Q1 in its focus on actual judicial practice by asking respondents whether they believed the prison sentences imposed by courts for corporate and financial wrongdoing were adequate. Table 4 below shows that just over half of the respondents $(51.83 \%)$ either strongly disagreed or disagreed with this proposition and just over a fifth (21.97\%) either strongly agreed or agreed that prison sentences imposed were adequate. The weighted average of 2.58 reflected that strong opinions were a little less evident than in Q1 and Q2 and can be partially explained by a significant number of respondents $(26.20 \%)$ stating that they had no opinion on this issue.

Table 4. Adequacy of prison sentences for corporate and financial wrongdoing

Q.4 Prison sentences imposed by courts for corporate and financial wrongdoing are adequate

\begin{tabular}{|l|l|l|l|l|l|l|l|}
\hline $\begin{array}{l}\text { Answer } \\
\text { Options }\end{array}$ & $\begin{array}{l}\text { Strongly } \\
\text { disagree }\end{array}$ & Disagree & No opinion & Agree & $\begin{array}{l}\text { Strongly } \\
\text { agree }\end{array}$ & $\begin{array}{l}\text { Weighted } \\
\text { Average }\end{array}$ & $\begin{array}{l}\text { Response } \\
\text { Count }\end{array}$ \\
\hline & $\begin{array}{l}50 \\
(14.08 \%)\end{array}$ & $134(37.75 \%)$ & $93(26.20 \%)$ & $\begin{array}{l}71 \\
(20.00 \%)\end{array}$ & $7(1.97 \%)$ & 2.58 & 355 \\
\hline
\end{tabular}

This question was an emotive issue for some of the respondents and this is reflected in some of the responses. For example:

I am dismayed by the inconsistency between prison sentences for white collar crime and far more heinous crimes. Corporate and financial wrongdoing does represent a breach of trust and position of course, but when a person is sent to prison for ten years for tax evasion (for example), and another person found guilty of rape gets a twelve month term, I think there is something very wrong with our judicial system.

However, others were critical of sentencing practice for corporate and financial wrongdoing:

This is one area that needs adjusting for the wrongdoing. Hundreds and thousands of people can lose their life savings and the perpetrators get minimum sentence. 
Rarely do you see people go to jail for corporate and financial wrongdoing; which often has a far more detrimental effect then other petty crimes people are jailed for.

These last two comments reflect a widespread perception that courts apply imprisonment terms towards business offenders in a cautious and conservative manner. This is a topic that crosses many issues, sentencing sites and sectors but there are empirical studies that lend support to such a view. ${ }^{18}$ However, the contrasting views amongst the cohort as a whole attest not only to the need for more visibility and knowledge regarding the data that exists about the actual sentencing reality for corporate and financial wrongdoing, but also the need for more depth regarding such data in the future.

Q5 stayed with the survey's central goal of probing into the capacity of penalties regimes to counter corporate and financial wrongdoing by asking respondents whether banning orders that ASIC imposes on corporate and financial wrongdoers are adequate (i.e. orders that prohibit an individual from managing corporations, providing financial services, or engaging in credit activities for a specified period of time). Table 5 below shows the overall results, there was a majority, (57.38\%) that strongly disagreed or disagreed, and a third (33.81\%) strongly agreed or agreed that ASIC banning orders are adequate, with a weighted average of 2.65 which indicates that as with Q4 views expressed by respondents were not heavily emphasising the strongest agreement or disagreement.

Table 5. Adequacy of banning orders for corporate and financial wrongdoing

Q.5 Banning orders that ASIC imposes on corporate and financial wrongdoers are adequate (i.e. orders that prohibit an individual from managing corporations, providing financial services, or engaging in credit activities for a specified period of time)

\begin{tabular}{|l|l|l|l|l|l|l|l|}
\hline $\begin{array}{l}\text { Answer } \\
\text { Options }\end{array}$ & $\begin{array}{l}\text { Strongly } \\
\text { disagree }\end{array}$ & Disagree & No opinion & Agree & $\begin{array}{l}\text { Strongly } \\
\text { agree }\end{array}$ & $\begin{array}{l}\text { Weighted } \\
\text { Average }\end{array}$ & Response Count \\
\hline & $\begin{array}{l}47 \\
(13.35 \%)\end{array}$ & $155(44.03 \%)$ & $31(8.81 \%)$ & $\begin{array}{l}112 \\
(31.82 \%)\end{array}$ & $7(1.99 \%)$ & 2.65 & 352 \\
\hline
\end{tabular}

Q6 asked whether ASIC should be provided with the ability to require disgorgement (i.e. the ability to recover from wrongdoers financial gains that they obtained as a result of their wrongdoing). Table 6 below shows that there was very strong support for this innovation with 93.75\% strongly agreeing or agreeing and only $3.98 \%$ strongly disagreeing or disagreeing. The weighted average of 4.44 demonstrates that this view was strongly held in the positive. Some of the comments by respondents attest to this. For example:

Absolutely - companies, their directors and executives should be required to offer full restitution [to] victims for their wrongdoings. The current regime is too weak, and does not result in adequate compensation being paid.

The concept of disgorgement is vital to create the necessary motivation for individuals to stay on the straight and narrow. Too many law breakers are prepared to commit offences as the pot of gold is always sitting there at the end of their sentences when they get out of gaol.

Table 6. Should ASIC be provided with disgorgement powers?

\footnotetext{
${ }^{18}$ See for example: Bird, H. and Gilligan, G. "Deterring corporate wrongdoing: Penalties, financial services misconduct and the Corporations Act 2001 (Cth)", (2016), Company and Securities Law Journal, 34, pp.332-35.
} 
Q.6 ASIC should be provided with the ability to require disgorgement (i.e. the ability to recover from wrongdoers financial gains that they obtained as a result of their wrongdoing)

\begin{tabular}{|l|l|l|l|l|l|l|l|}
\hline $\begin{array}{l}\text { Answer } \\
\text { Options }\end{array}$ & $\begin{array}{l}\text { Strongly } \\
\text { disagree }\end{array}$ & Disagree & No opinion & Agree & $\begin{array}{l}\text { Strongly } \\
\text { agree }\end{array}$ & $\begin{array}{l}\text { Weighted } \\
\text { Average }\end{array}$ & $\begin{array}{l}\text { Response } \\
\text { Count }\end{array}$ \\
\hline & $4(1.14 \%)$ & $10(2.84 \%)$ & $8(2.27 \%)$ & $\begin{array}{l}134 \\
(38.07 \%)\end{array}$ & $\begin{array}{l}196 \\
(55.68 \%)\end{array}$ & 4.44 & 352 \\
\hline
\end{tabular}

Despite the preceding comments the very strong support amongst respondents overall for ASIC to be given disgorgement powers is likely to be welcomed by ASIC. However it might feel less sanguine about responses to Q7 which asked whether ASIC enforces corporate and financial laws in a manner that is quick and efficient. As Table 7 below shows only $7.95 \%$ strongly agreed or agreed with this proposition and $74.72 \%$ strongly disagreed or disagreed. The weighted average of 2.09 demonstrates that this view was strongly held in the negative.

Some of the respondents were sympathetic towards ASIC and what it could reasonably be expected to achieve given its level of funding. For example:

They have been under-resourced historically, and have not performed as efficiently and effectively as some of the other regulatory bodies (e.g. APRA). The recent financial increases announced in the Federal Budget should help ASIC in their supervisory role.

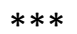

Too slow and too few enforcements for the number of issues in the corporate world. That is presumably a function of funding cuts to ASIC.

$* * *$

ASIC do not have the resources to respond in a timely manner - they do the best they can given the people and dollars they have. They could do more if they were given the resources.

Table 7. Does ASIC enforce corporate and financial laws quickly and efficiently?

Q.7 ASIC enforces corporate and financial laws in a manner that is quick and efficient

\begin{tabular}{|l|l|l|l|l|l|l|l|}
\hline $\begin{array}{l}\text { Answer } \\
\text { Options }\end{array}$ & $\begin{array}{l}\text { Strongly } \\
\text { disagree }\end{array}$ & Disagree & $\begin{array}{l}\text { No } \\
\text { opinion }\end{array}$ & Agree & $\begin{array}{l}\text { Strongly } \\
\text { agree }\end{array}$ & $\begin{array}{l}\text { Weighted } \\
\text { Average }\end{array}$ & $\begin{array}{l}\text { Response } \\
\text { Count }\end{array}$ \\
\hline & $\begin{array}{l}90 \\
(25.57 \%)\end{array}$ & $\begin{array}{l}173 \\
(49.15 \%)\end{array}$ & $\begin{array}{l}61 \\
(17.33 \%)\end{array}$ & $25(7.10 \%)$ & $3(0.85 \%)$ & 2.09 & 352 \\
\hline
\end{tabular}

As evidenced in some of the additional comments for $Q 7$ the issue of available resources is of course a crucial factor in whether an agency such as ASIC is able to carry out its mandate in a quick and efficient manner. Consequently Q8 asked respondents whether they believed that ASIC has sufficient funding and other resources to counter corporate and financial wrongdoing effectively. As Table 8 below shows only $8.55 \%$ strongly agreed or agreed with this proposition and $69.24 \%$ strongly disagreed or disagreed. The weighted average of 2.12 demonstrates that this view was strongly held in the negative.

Table 8. Is ASIC sufficiently funded to counter corporate and financial wrongdoing effectively? 
Q.8 ASIC has sufficient funding and other resources to counter corporate and financial wrongdoing effectively

\begin{tabular}{|l|l|l|l|l|l|l|l|}
\hline $\begin{array}{l}\text { Answer } \\
\text { Options }\end{array}$ & $\begin{array}{l}\text { Strongly } \\
\text { disagree }\end{array}$ & Disagree & No opinion & Agree & $\begin{array}{l}\text { Strongly } \\
\text { agree }\end{array}$ & $\begin{array}{l}\text { Weighted } \\
\text { Average }\end{array}$ & $\begin{array}{l}\text { Response } \\
\text { Count }\end{array}$ \\
\hline & $\begin{array}{l}99 \\
(28.21 \%)\end{array}$ & $\begin{array}{l}144 \\
(41.03 \%)\end{array}$ & $\begin{array}{l}78 \\
(22.22 \%)\end{array}$ & $26(7.41 \%)$ & $4(1.14 \%)$ & 2.12 & 351 \\
\hline
\end{tabular}

Q9 asked whether the penalties imposed for corporate and financial wrongdoing are sufficiently reported and publicised. As Table 9 below shows approximately double the number of respondents answered in the negative (59.83\% strongly disagreed or disagreed), compared to those who answered in the positive ( $30.20 \%$ strongly agreed or agreed), and this is reflected in the weighted average of 2.61 .

Table 9. Are penalties for corporate and financial wrongdoing sufficiently reported and publicised?

Q.9 The penalties imposed for corporate and financial wrongdoing are sufficiently reported and publicised

\begin{tabular}{|l|l|l|l|l|l|l|l|}
\hline $\begin{array}{l}\text { Answer } \\
\text { Options }\end{array}$ & $\begin{array}{l}\text { Strongly } \\
\text { disagree }\end{array}$ & Disagree & No opinion & Agree & $\begin{array}{l}\text { Strongly } \\
\text { agree }\end{array}$ & $\begin{array}{l}\text { Weighted } \\
\text { Average }\end{array}$ & $\begin{array}{l}\text { Response } \\
\text { Count }\end{array}$ \\
\hline & $\begin{array}{l}44 \\
(12.54 \%)\end{array}$ & $\begin{array}{l}166 \\
(47.29 \%)\end{array}$ & $35(9.97 \%)$ & $96(27.35 \%)$ & $10(2.85 \%)$ & 2.61 & 351 \\
\hline
\end{tabular}

Having canvassed the adequacy of reporting and publicity processes Q10 sought the views of respondents on the relative importance of the penal goals that underpin penalties regimes as can be seen in Table 10 below.

Table 10. Punishment rationales and penalties for corporate and financial wrongdoing

Q.10 How important are the below reasons for imposing penalties for corporate and financial wrongdoing?

\begin{tabular}{|l|l|l|l|l|l|l|l|}
\hline Answer Options & $\begin{array}{l}\text { Not at all } \\
\text { important }\end{array}$ & $\begin{array}{l}\text { Slightly } \\
\text { important }\end{array}$ & $\begin{array}{l}\text { Moderately } \\
\text { important }\end{array}$ & $\begin{array}{l}\text { Very } \\
\text { important }\end{array}$ & $\begin{array}{l}\text { Extremely } \\
\text { important }\end{array}$ & $\begin{array}{l}\text { Weighted } \\
\text { Average }\end{array}$ & $\begin{array}{l}\text { Response } \\
\text { Count }\end{array}$ \\
\hline $\begin{array}{l}\text { To compensate victims } \\
\text { for loss or harm resulting } \\
\text { from the wrongdoing }\end{array}$ & $8(2.29 \%)$ & $15(4.29 \%)$ & $55(15.71 \%)$ & $\begin{array}{l}160 \\
(45.71 \%)\end{array}$ & $\begin{array}{l}112 \\
(32.00 \%)\end{array}$ & 4.01 & 350 \\
\hline $\begin{array}{l}\text { To punish the } \\
\text { wrongdoers }\end{array}$ & $0(0.00 \%)$ & $2(0.57 \%)$ & $28(8.00 \%)$ & $\begin{array}{l}146 \\
(41.71 \%)\end{array}$ & $\begin{array}{l}174 \\
(49.71 \%)\end{array}$ & 4.41 & 350 \\
\hline $\begin{array}{l}\text { To incapacitate the } \\
\text { wrongdoers so that they } \\
\text { cannot reoffend }\end{array}$ & $12(3.43 \%)$ & $19(5.43 \%)$ & $58(16.57 \%)$ & $\begin{array}{l}116 \\
(33.14 \%)\end{array}$ & $\begin{array}{l}145 \\
(41.43 \%)\end{array}$ & 4.04 & 350 \\
\hline $\begin{array}{l}\text { To deter other potential } \\
\text { wrongdoers from } \\
\text { engaging in similar } \\
\text { wrongdoing }\end{array}$ & $0(0.00 \%)$ & $5(1.43 \%)$ & $34(9.71 \%)$ & $\begin{array}{l}120 \\
(34.29 \%)\end{array}$ & $\begin{array}{l}191 \\
(54.57 \%)\end{array}$ & 4.42 & 350 \\
\hline $\begin{array}{l}\text { To rehabilitate the } \\
\text { wrongdoers so that they } \\
\text { are less likely to reoffend }\end{array}$ & $\begin{array}{l}51 \\
(14.57 \%)\end{array}$ & $\begin{array}{l}74 \\
(21.14 \%)\end{array}$ & $90(25.71 \%)$ & $\begin{array}{l}88 \\
(25.14 \%)\end{array}$ & $\begin{array}{l}47 \\
(13.43 \%)\end{array}$ & 3.02 & 350 \\
\hline
\end{tabular}

The weighted average scores reveal the intensity of the views that respondents held regarding the various penal rationales. For example, deterrence was viewed as extremely important by the most respondents $(n=191)$ in comparison to the other four penalties rationales. So in terms of the 
strength of respondents' answers about the importance of the five rationales, it can be seen that deterrence was held most strongly (4.42), closely followed by punishment (4.41), incapacitation (4.04), compensation (4.01) and interestingly rehabilitation (3.02) was viewed as much less important. In order to adopt a similar approach to how responses to questions 1-9 were tabulated the responses to Q10 were aggregated into percentage scores. The 'High importance' category combines the very important and extremely important responses, the 'Low importance' category combines the slightly important and not at all important responses. The moderately important responses were considered to equate with the no opinion category of responses to questions 1-9. Obviously selecting the response moderately important is expressing an opinion but the authors wanted to retain a similar comparative approach to that utilised for questions 1-9. This approach permits the translation of the overall results shown in Table 10 into a ranking of the five rationales in terms of importance to the respondents as a group. These results are shown in Table 11 below.

Table 11. Ranking of penal rationales by importance $(n=350)$

\begin{tabular}{|l|l|l|l|}
\hline Penal Rationale & High Importance & Low Importance & Ranking \\
\hline To punish the wrongdoers & $91.4 \%$ & $0.6 \%$ & 1 \\
\hline $\begin{array}{l}\text { To deter other potential wrongdoers from engaging in } \\
\text { similar wrongdoing }\end{array}$ & $88.9 \%$ & $1.4 \%$ & 2 \\
\hline $\begin{array}{l}\text { To compensate victims for loss or harm resulting from } \\
\text { the wrongdoing }\end{array}$ & $77.7 \%$ & $6.6 \%$ & 3 \\
\hline $\begin{array}{l}\text { To incapacitate the wrongdoers so that they cannot } \\
\text { reoffend }\end{array}$ & $74.6 \%$ & $8.9 \%$ & 4 \\
\hline $\begin{array}{l}\text { To rehabilitate the wrongdoers so that they are less } \\
\text { likely to reoffend }\end{array}$ & $38.6 \%$ & $35.7 \%$ & 5 \\
\hline
\end{tabular}

It can be seen from Table 11 that punishing wrongdoers (91.4\%), i.e. retribution, was seen by the respondents as a group as the most important penal rationale, followed closely by deterring other potential wrongdoers $(88.9 \%)$, thereby reversing the order between these two rationales regarding intensity of opinion as per the weighted averages shown in Table 10. This is because a slightly higher number of respondents $(n=320)$ placed punishing wrongdoers in the combined extremely important or very important categories than they did for deterrence $(n=311)$. Compensating victims $(77.7 \%)$ was considered third most important, incapacitating wrongdoers fourth (74.6\%) and some way behind in fifth rehabilitation (38.6\%). This relatively low score for rehabilitation is discussed further below as is the high priority given to retribution in punishment which is of particular interest given ASIC's repeated emphases on deterrence as its key rationale. ${ }^{19}$

Table 12. Suggestions for improving penalties systems for corporate and financial wrongdoing

Q. 11 Do you have any further suggestions for how penalties for corporate and financial wrongdoing could be improved, either in terms of the penalties themselves or how they are administered by ASIC and the courts?

\begin{tabular}{|l|l|l|}
\hline Answer Options & Response Percent & Response Count \\
\hline No, I do not have any further suggestions & $74.5 \%$ & 260 \\
\hline Yes, my further suggestions are: & $25.5 \%$ & 89 \\
\hline
\end{tabular}

\footnotetext{
${ }^{19}$ See $f n 15$ and discussion in Part I.
} 
There were a number of issues that were emphasised in comments from the respondents. As was evidenced in the overall responses to questions throughout the survey many respondents felt that available penalties were simply too low and not achieving sufficient deterrent impact. For example:

Greater penalties both civil and criminal.

Need to increase penalties to at least double or triple.

Similarly resourcing of ASIC was seen as a significant problem by many respondents. For example:

ASIC needs more funding so that it doesn't have to choose which cases to run and can run all cases where sufficient evidence of wrongdoing exists. ASIC should be a regulator whom directors respect and fear.

$* * *$

Provide ASIC with additional resources to detect and prosecute offenders and allow ASIC to educate the corporate world.

Some respondents linked the need for greater ASIC resourcing with other initiatives, for example increasing protections and incentives for whistleblowers:

ASIC does not have the funding to pursue many smaller wrongdoers, and cannot recover much from them even if successful. While further funding for ASIC would help, ASIC needs assistance to identify wrongdoers and pursue them early and quickly, before they can fritter away corporate funds. How about a whistleblower scheme where the whistleblower gets a percentage of any ill-gotten gains which ASIC subsequently recovers? Whistleblowers currently have no financial upside in acting as whistleblowers, and risk their livelihoods and reputations if they are exposed - give them a monetary incentive. One or two successful whistleblowers will encourage many others to come forward, particularly on issues which affect them - for example, employers who misappropriate their employee's superannuation contributions.

There should be greater mechanisms to allow for whistleblowing so that ASIC and other professional bodies actually become aware of misconduct amongst corporate Australia. In a time when everyone is being asked to do more with less resources, it is a common theme that short-cuts in compliance regimes and unethical conduct is occurring so that profit margins can be retained and improved.

These respondents would be heartened by the reforms flagged in its 2016-2017 Federal Budget by the Commonwealth Government to increase protections for whistleblowers and the current inquiry by the Treasury to evaluate protections for tax whistleblowers and assess the adequacy of existing whistleblower protections in the corporate sector. ${ }^{20}$

Similarly, several respondents commented on the need to increase ASIC's available powers and introduce specialisation of judicial processes. For example:

\footnotetext{
${ }^{20}$ Australian Government, The Treasury, Review of Tax and Corporate Whistleblower Protections in Australia, http://www.treasury.gov.au/ConsultationsandReviews/Consultations/2016/Review-of-whistleblowerprotections
} 
ASIC needs to be empowered with more powers so that cases relating to corporate and financial wrongdoing are not dragged in the Courts system for years and years on end. ASIC could instead have some important powers which are swift and timely. Consideration should also be given to have a separate judiciary system for administering cases relating to corporate and financial wrongdoing. This will certainly take away the current work pressure on High/Federal Courts.

Set up an ASIC specific court system. Federal to fast track/process offenders both for corporate and criminal offences - available in Magistrates courts across Australia. Also, more widely publically publish all civil and criminal successful prosecutions, also include in this ATO successes - Not to drive a culture of fear...but to drive a culture of risk aversion to wrongdoing. If you offend you will be caught and punished financially, civillyand/or criminally.

This issue of possibly establishing special courts for corporate and financial wrongdoing is a complex one that straddles political, social and cultural tensions, as well as business and legal dilemmas, and that is before considering the cost and other pragmatic implications of such innovation. However, the comments reflect a frustration amongst the respondents that existing arrangements are not serving either the business sector or the wider community as they should, and that there is an obligation as well as a need to impact upon and improve business practice.

Timeliness and transparency regarding penalties were important issues for respondents, for example:

How penalties are calculated should be more transparent and subject to more effective administrative review. A penalty imposed without explanation for how it is calculated or that appears capricious will have less deterrent effect than one that is clearly linked to certain bad decisions or conduct of the wrongdoer and can be validated through a review process that is credible. The punishment should be commensurate with and fit the crime.

These situations need to be dealt with in a much quicker manner. Innocents go broke waiting for restitution and it can be years before white collar crime is brought before the courts thereby allowing corrupt directors/company officers tocontinue operating for some time.

$* * *$

Quick action is important both in respect of opportunities for the wrongdoer to prepare for the outcome and in strengthening public confidence in the existing mechanisms.

Amongst the respondents, linked with these notions of justice delayed is justice denied and the need for increased transparency were suggestions to increase the profile of ASIC's enforcement activities and better inform the public. For example:

A public register of offenders.

A dedicated penalties.gov.au website that displays and summarises corporate and financial wrongdoing. 
The penalty, financial or otherwise must be a deterrent. Cases must be very heavily advertised to name and shame.

ASIC has been increasingly utilising technology to profile its activities in recent years, including media releases regarding specific instances of enforcement, plus discussion papers and reports on a range of issues, as well as useful educative resources such as its Money Smart website. ${ }^{21}$ All of these perform useful functions but there was a sense amongst the respondents that ASIC is still not doing enough to inform the public in easily accessible ways about the specifics of penalties regimes and who were individuals and organisations subject to such penalties regimes.

\section{Part III Conclusion}

The further suggestions from respondents when replying to Q11 reflect the overall view of the cohort when answering questions 1-10 that penalties regimes in Australia to counter corporate misconduct are not adequate. It is worth recapping how the overall cohort viewed issues regarding penalties regimes for corporate and financial wrongdoing. Monetary penalties imposed by the courts are not adequate (see Table 1), neither are prison terms (see Table 4), nor are maxima civil penalties that can be imposed by the court for a single contravention of the Corporations Act 2001 (see Table 2). There was overall, but less strong support for not having maxima on penalties (see Table 3) and ASIC banning orders were not viewed as adequate (see Table 5). There was extremely strong support for equipping ASIC with disgorgement powers (see Table 6), support also for increasing funding and other resources to ASIC (see Table 8), but substantial dissatisfaction not only with how quickly and efficiently ASIC enforces corporate and financial laws (see Table 7) but also how penalties are reported and publicised (see Table 9). Deterrence and punishment were clearly viewed as the most important rationales that should underpin penalties regimes, but compensation and incapacitation were also regarded as very important, and the cohort was split as to whether rehabilitation was an important penal rationale (see Tables 10 and 11).

The results of this survey do not provide a comprehensive picture of penalties regimes and their effects upon corporate and financial wrongdoing in Australia. However, governance professionals are key internal gatekeepers in efforts to counter such wrongdoing and so the views and opinions reported in this survey are important. The primary data presented in this paper is a valuable addition to the policy discourse on how penalties regimes to counter corporate and financial wrongdoing in Australia are operating and how they might be improved in the future.

\footnotetext{
${ }^{21}$ See https://www.moneysmart.gov.au/
} 